\title{
Correction to: Osteoporosis in patients with rheumatoid arthritis: trends in the German National Database 2007-2017
}

\author{
Lisa Lindner ${ }^{1}\left(\mathbb{D} \cdot\right.$ Johanna Callhoff $^{1}(\mathbb{C}) \cdot$ Rieke Alten $^{2}\left(\mathbb{D} \cdot\right.$ Andreas Krause $^{3} \cdot$ Wolfgang Ochs $^{4} \cdot$ Angela Zink $^{1,5}$ (D) \\ Katinka Albrecht ${ }^{1}$ (1)
}

Published online: 16 October 2020

○) Springer-Verlag GmbH Germany, part of Springer Nature 2020

\section{Correction to: Rheumatology International https://doi.org/10.1007/s00296-020-04593-6}

In the original article, under the abstract and result section: Osteoporosis frequency in RA patients (mean age 63 years, $75 \%$ female) decreased from $20 \%$ in 2007 to $6 \%$ in 2017 $(p<0.001)$. The values given are incorrect.

In both sentences, $6 \%$ needs to be replaced by $15 \%$, this corresponds to the correct information in Table 3.

The authors have overlooked the errors during proof corrections stage.
The original article can be found online at https://doi.org/10.1007/ s00296-020-04593-6.

Lisa Lindner

lisa.lindner@drfz.de

Johanna Callhoff

Johanna.callhoff@drfz.de

Rieke Alten

Rieke.Alten@schlosspark-klinik.de

Andreas Krause

a.krause@immanuel.de

Wolfgang Ochs

rheuma.ochs@gmx.de

Angela Zink

zink@drfz.de

Katinka Albrecht

Albrecht@drfz.de
Publisher's Note Springer Nature remains neutral with regard to jurisdictional claims in published maps and institutional affiliations.
1 Epidemiology Division, German Rheumatism Research Center (DRFZ), Charitéplatz 1, 10117 Berlin, Germany

2 Schlosspark Klinik, Internal Medicine 2, Rheumatology, Clinical Immunology and Osteology, Berlin, Germany

3 Immanuel Hospital, Rheumatology and Clinical Immunology, Berlin, Germany

4 Rheumatism Practice Bayreuth, Bayreuth, Germany

5 Medical Clinic with Focus on Rheumatology and Clinical Immunology, Charité - Universitätsmedizin, Berlin, Germany 